\title{
Development Entrepreneurship Intention Among Students
}

\author{
Meithiana Indrasari ${ }^{1}$, Raditya Bambang Purnomo ${ }^{2}$, Nur Syamsudin ${ }^{3}$, Eddy Yunus ${ }^{4}$ \\ ${ }^{1,2,4}$ Faculty of Economics and Business, University of Dr. Soetomo Surabaya, \\ ${ }^{3}$ Faculty of Social and Politic Science, The State Islamic University Walisongo Semarang \\ E-mail: meithiana.indrasari@unitomo.ac.id
}

\begin{tabular}{|c|c|c||}
\hline Accepted : & Reviewed : \\
November, 03 2017 & Published : \\
January, 03 2018 & March 2018 \\
\hline
\end{tabular}

\begin{abstract}
Purpose: This study aims to describe the actual conditions of student entrepreneurship intentions in the Faculty of Economics and Business of Dr. Soetomo University, to identify the determinants of students' entrepreneurship intent and to formulate methods of approach to improve student entrepreneurship intentions.

Design/methodology/approach: This research is a qualitative research with phenomenological approach, where researchers try to explain or reveal the meaning of the concept or the phenomenon of experience based on awareness that occurs in some individuals.

Findings: the general intention of entrepreneurship students are still relatively low evidenced by lack of individual and group FEB students become entrepreneurs, lack of student involvement in the training and equipping of entrepreneurship within and outside the campus environment and the lack of the number of business proposals that competed in the Student Entrepreneurial Program (PMW) Higher Education.

Research limitations/implications: student entrepreneurship intentions in the Faculty of Economics and Business of Dr. Soetomo University.

Practical implications: This article tries to explain how the academic role of campus in cultivating the intention of entrepreneurship to students by using the theory of intention that is the theory of planned behavior.

Originality/value: In this study the researchers collect, summarize and interpret the data obtained, which then reprocessed so that obtained a clear picture, directed and comprehensive of the problem that became the object of research. The phenomenological approach is used to analyze the original data collected from interview questions and dialogue with informants. The structure of experience is illustrated by the researchers' interpretation of the participant description.
\end{abstract}

Paper type: Research paper

Keywords: entrepreneurship, entrepreneurship intention, students, phenomenology

\section{INTRODUCTION}

Indonesia is one among the many developing countries which have problems with poverty and unemployment. Start with low education even up to the highly educated have difficulties in finding a job. This happens because many labor force wants to enter the world of work is not comparable with the number of jobs available. The gap between supply and demand of labor breeds poverty.

One of the factors that lead to high levels of unemployment in Indonesia is the perception that it is easier to find a job in the formal sector as an employee or employees, which led to so many people who do not try to create their own jobs in the micro business sector. This clearly affects economic growth in Indonesia. It is deemed very necessary to find solutions to overcome unemployment. One solution for someone to have the economic ability to live life without the drape himself to be an employee or employees is to provide education and training in order to become microentrepreneurs. The result is the availability of jobs for others. In becoming an entrepreneur, what is needed is the provision of sufficient entrepreneurial skills.

According to data from the Central Statistics Agency in August 2010, the total labor force reached 116.5 million, an increase of approximately 530 thousand people compared to February 2010 and up to 2.7 million people compared with August 2009. Residents who work in August 2010 increased 800 thousand people compared to February 2010, and up 3.3 million people compared to August 2010. the number of unemployed in Development Entrepreneurship Intention Among Students 
August 2010 has decreased by about 270 thousand people compared to February 2010 and declined to 640 thousand when compared with August 2009 (CBS, 2012),

Table 1. Population-Based Shape Key Activities, 2008-2010 (in millions)

\begin{tabular}{|c|c|c|c|c|c|}
\hline \multirow[t]{2}{*}{ Shape Main Activities } & 2008 & \multicolumn{2}{|c|}{2009} & \multicolumn{2}{|c|}{2010} \\
\hline & August & February & August & February & August \\
\hline Population15+ & 166.64 & 168.26 & & 113.74 & \\
\hline Labor & 111.95 & & & 104.499 .26 & \\
\hline Working & 102.55 & & & 169.33 & \\
\hline Not Working & 9.39 & & & 113.83 & \\
\hline & & & & 104.878 .96 & \\
\hline & & & & 171.02 & \\
\hline
\end{tabular}

In August 2010, about 35.8 million people (33.06\%) work in the formal sector and 72.4 million (66.94\%) work in informal activities. Of the 108.2 million people who work in August 2010, work as laborers and employees totaled 32.5 million (30.05\%), self-employed assisted by temporary laborers 21.7 million (20.04\%), and selfemployed 21.0 million (19.44\%), while the smallest is self-employed assisted by permanent workers, 3.3 million people (3.01\%). In the previous year (August 2009 - August 2010) there are additional workers to the status of workers and employees of 3.4 million people, and the families of workers a total of 570 thousand people. While the status of workers in the agricultural sector decreased by 64 thousand people (CBS, 2012).

From the above data, we can see that the level of entrepreneurship in Indonesia is still very low when compared with other countries. In the United States approximately 11\%, Singapore 7\%, while in Indonesia is only $0.24 \%$ of the approximately 237.6 million people in Indonesia who have the entrepreneurial competence. This condition also affects the unemployment rate. workers tend to want to be a worker, or bureaucrats in government offices and not creators of new jobs (Dipta, 2015).

To reach the level of prosperity is not an easy task. Many changes are needed, effort and hard work that is focused and systematic way by the Government, and the family, especially for individual change from the present to become entrepreneurs needed. Being an entrepreneur should not be an alternative profession, but being an entrepreneur is a strategic choice that has to do with determination. Under current conditions, it can be said that the key to prosperity is entrepreneurship, and entrepreneurship is a very promising profession in promoting quality of life.

To foster entrepreneurship intention then it takes some effort to support the growth of entrepreneurship in the student's intentions. One of the things that could support the growth of entrepreneurship intention is education where entrepreneurship education is an education that teaches a person to be willing and able to create their own business activities (Eman Suherman, 2008).

Several studies have shown that entrepreneurship intention is the key constructs that define the entrepreneurial behavior (Andie \& Madjid, 2012). Individuals who have a strong intention to start a business will have a great tendency to open their own business. According to Krueger et al (Kueger \& Carsrud, 2000), involvement in entrepreneurial activity does not happen by itself, but rather intentional by the person concerned. This means that to start a business, one must have the intention to start a business. So the intention of entrepreneurship can be said to be a strong predictor for determining whether someone will decide to selfemployed or not.

Obschonka et al (2010) found that entrepreneurship can be developed through education and can be started at an early age. The social environment and the people around individuals engaged in entrepreneurial activities, such as family or friends, can affect a person's attitude towards entrepreneurship. Conversely, those who did not grow up in an entrepreneurial environment, it will tend to be an employee in the future (Mueller, 2008).

From this perspective, this article tries to explain how the environment can affect the development of the campus academic entrepreneurial intention among the students.

\section{educated unemployment}


Government efforts to lower the unemployment rate has shown improvement. Nevertheless, the unemployment rate of educated over the last few years seems constantly increasing. According to the Central Statistics Agency (BPS-2017), the number of Unemployed Diploma level, increased every year from 241.312 people in 2015 to 249.705 people in 2017. Graduate Unemployment also continues to grow, in 2015 there were 585.402 people Bachelor of unemployed in 2017 increased to 606.939 people. In detail, the unemployment rate by education can be seen in Table 1 below.

Table 1. Unemployment byAttainment Levels Yang Educational

\begin{tabular}{|l|r|r|r|}
\hline \multicolumn{1}{|c|}{ EducationalYangAttainment } & \multicolumn{1}{c|}{$\mathbf{2 0 1 5}$} & \multicolumn{1}{c|}{$\mathbf{2 0 1 6}$} & \multicolumn{1}{c|}{$\mathbf{2 0 1 7}$} \\
\hline Not Educational & 124.303 & 94.293 & 92.331 \\
\hline Not Completed Elementry School & 603.194 & 557.418 & 546.897 \\
\hline Elementry School & $1,218,954$ & & $1,320,392$ \\
& $1,292,234$ & & $1,650,387$ \\
\hline junior high school & $1,313,815$ & & $1,762,411$ \\
& $1,281,240$ & & \\
\hline senior high school & $2,280,029$ & & $1,174,366$ \\
& $1,552,894$ & & 249.705 \\
\hline vocational & $1,348,327$ & & 606.939 \\
\hline Diploma & $1,383,022$ & & \\
\hline University & 241.312 & 249.362 & \\
\hline
\end{tabular}

Description: BPS processed (data as of February 2017)

There are two things to be learned from the development of the unemployment rate. First, a good basic education to upper secondary school and graduated from university was not yet able to produce graduates who are ready to use, either as an employee or as a force that has the necessary capabilities the business world. Second, education is implemented in Indonesia, the curriculum is always changing almost every change of government has not been able to address global challenges, particularly with regard to the growth of new entrepreneurial phenomenon above is not off-hook, the education system has not been able to produce graduates who are ready to use and answer the challenges of needs the labor market. The education system should be able to produce graduates who are ready to create new jobs. The educated workforce should have an instinct to want to take advantage of opportunities, risk-taking, creative, and innovative. If each level of education has been promoting the importance of entrepreneurship, then it should be the number of unemployed is increasing every year, although it was realized that a conducive business climate influences. Climate conducive business without the support of the graduates of education that does not have the benefit of entrepreneurship will be wasted, and vice versa.

\section{Entrepreneurship intention}

The intention is assumed as motivating factors that influence the behavior, which shows how hard someone will try to realize a behavior (Ajzen, 1991). Along with the definition, the intention of entrepreneurship is defined as a state of consciousness that directs the attention, experience, and behavior of people towards entrepreneurial behavior (Bird, 1988).

Intention entrepreneurship has proven to be the strongest predictors of entrepreneurial behavior. In its simplest form, can predict behavioral intention, and the intention itself is predicted by certain attitudes (Khuong and An, 2016). Studies conducted by Kristiansen \& Indarti (2004) shows that entrepreneurial intentions are influenced by gender, self-efficacy, educational background, and the readiness of instrumental (access to capital, availability of information, and social networks).

Theory of Planned Behavior developed by Fishbein and Ajzen often used to explain how the role of intention in the formation of behavior (Fishbein \& Ajzen, 2010). 


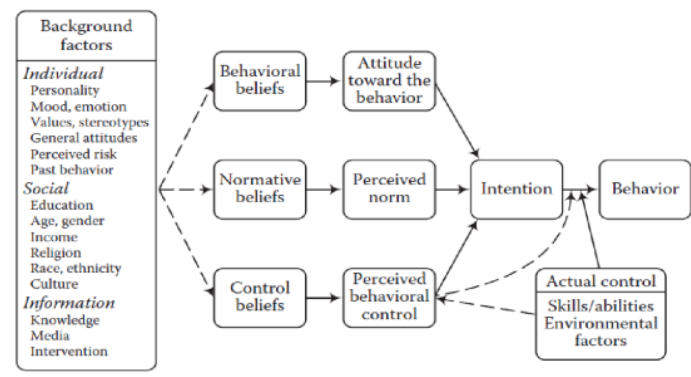

Figure 1. Theory of Planned Behavior of Fishbein \& Ajzen

Figure 1 shows that the intention is a major predictor of behavior, taking into account the skills/abilities and environmental factors. There are three things that affect intentions, the attitude toward the behavior, perceptions of norms, and behavior control. Someone will do something if he has a positive attitude towards such behavior and they feel norms around them requires them to do so. In addition, the assessment own ability to perform such behavior is also important. However, these three aspects have different levels based on the beliefs, norms, and certain controls. This explains why people with attitudes, norms, and perceptions of the same controls may behave differently, depending on which factors have a greater influence. It is at a level further analysis is influenced by individual factors, social, and information about behavior.

\section{METHODS}

This study is a qualitative research with a phenomenological approach, where researchers try to explain or reveal the meaning of the concept or phenomenon of experience based on the awareness that occurs in some individuals. In this study, researchers collect, summarize and interpret the data obtained, which then reprocessed in order to obtain a clear picture, directed and thorough of the problem which is the object of research. The phenomenological approach is used to analyze the original data collected from interview questions and dialogue with the informant. Structural interpretation of the experiences described by researchers in the description of the participants.

\section{CONCEPTUAL FRAMEWORK}

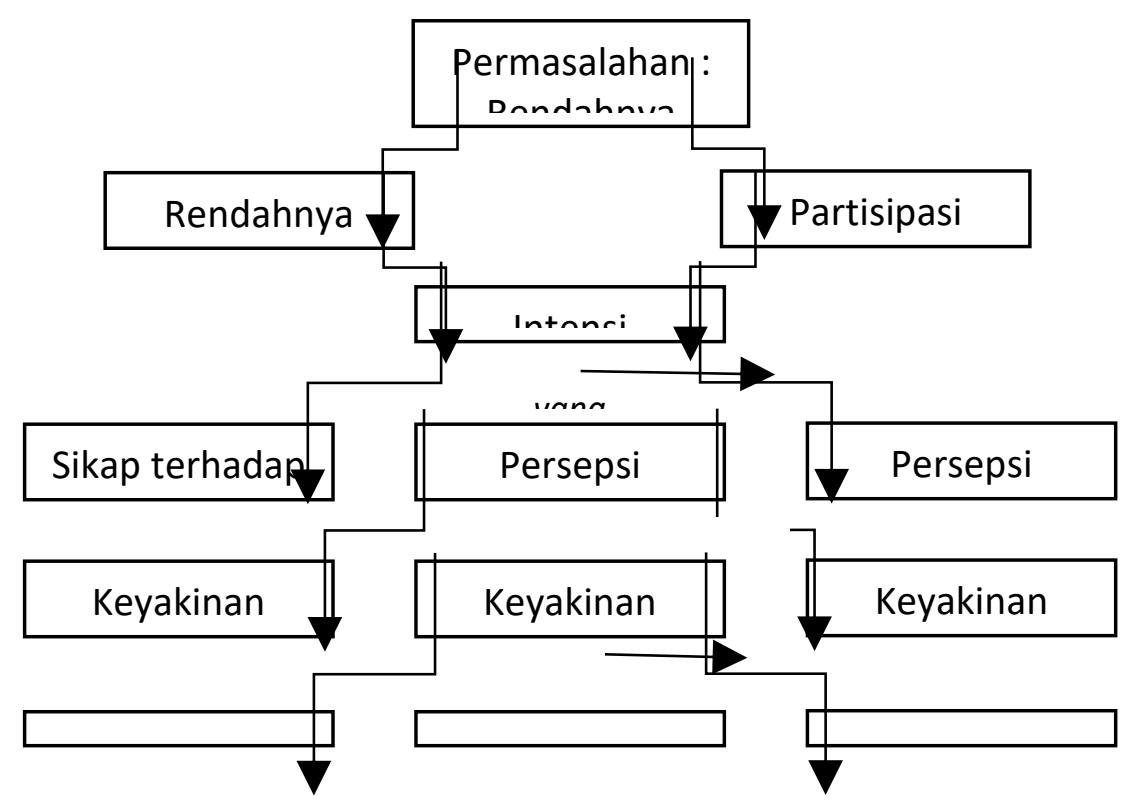




\section{FOR ENTREPRENEURIAL ATTITUDE}

Attitude is the evaluation of an object, either in general or specific level (Robinson et al, 1991). To measure attitudes toward a particular domain accurately, it is necessary to explain the dimensions of attitude in particular. There are two groups of theories about attitude, attitude as the unidimensional construct (Fishbein \& Ajzen, 1975) and attitude as a multidimensional construct (Rosenberg and Hovland, 1960). Unidimensional approach states that the attitude shown in the form of affective reactions, whereas a multidimensional approach or tripartite approach says that attitude is a combination of three forms of response, namely cognitive, affective, and conative. Cognitive component consists of individual beliefs and thoughts to the object attitude. The effective component consists of a positive or negative feeling towards the object attitude. The conative or behavioral component consists of the intention to act and the tendency to behave in a certain way towards the object.

Research shows that attitudes towards entrepreneurship are the direct and indirect effects of significant experience of their family business, through variable attitudes toward business ownership, support the school, and entrepreneurial self-efficacy (Carr \& Sequeira, 2007). In terms of the background of the work of parents, most of the respondents did not come from an entrepreneurial family. Average kind of profession of their parents is civil servants (in vertical and local agencies) and private sector employees. Only a small proportion of respondents answered backgrounds work as self-employed parents. As a result, his urge parents to actively seek independent business experience is very small.

Results Our interviews found that most respondents do not / never training, briefing, seminars, workshops and the like on entrepreneurship. In addition to the lack of information and dissemination of the organizers as well as student interest itself for the event is very low. For those respondents who had attended training in entrepreneurship also just implemented on an internal campus.

Entrepreneurship courses is a subject that must be followed by students in all departments/study programs at FEB Unitomo. One method used is the students are encouraged to undertake entrepreneurial activities by creating and marketing the product. This is done to encourage the creativity of students and find out how far the ability of students to become entrepreneurs. For some students, this activity is considered as a media exercise to hone their skills and interest in entrepreneurship, but for others, it will just demand to get the value only.

This proves that less entrepreneurial attitudes and actions can be explored by students independently. Though entrepreneurial attitude reflects the affective component of the student in response to business opportunities that involves a commitment to the implementation effort. Entrepreneur actions reflect undertaken by entrepreneurs reach their goals in business. Student entrepreneurial character consists of two main elements, namely the personality and confidence(Cahyono, 2017; Puspitasari and Harjanti, 2017; Syaifudin, 2017).

\section{TRANSMIT VALUE OF ENTREPRENEURSHIP IN STUDENTS}

There are many different types of norms. One kind of the norm refers to an attitude or what you think is the correct individual based on moral or belief(injunctive norm). The second type of norms related to the behavior, which is what really made the individual(descriptive norm). The researchers showed that the behavior is more likely to predict with injunctive norms than the descriptive norm (Borsari \& Carey, 2003). Every individual has a friend, a member of a group, stay in the dorms on college campuses, and is part of a larger community. Each group of overlapping has norms which may be the same or different, and some or all of these norms can influence the behavior of individuals. Among the targets of norms, misperceptions can increase with increasing social distance, and social groups are "close" more influential in shaping the behavior (Berkowitz, 2004). It can be concluded that the closeness between faculty and students can help shape social norms that are believed by students.

More specifically, Grusec and Goodnow (1994) state that there are two steps that occur in the process of the valuation between faculty and students. In the first step, the students have to really understand what the values instilled by lecturers want. Second, the student must accept these values as their own values. In the first step students can understand accurately, otherwise, there will be misperceptions about the value of invested lecturers. In other words, in order to enable the transmission, the value of embedded lecturers should be congruent with students' scores. Related to entrepreneurship, it is undeniable that if professors want their students to have a strong entrepreneurial intention, then the faculty will also need to adopt the values of entrepreneurship in themselves and 
their lives. Kecharananta \& Baker (1999) suggests these values include independence, creativity, cooperation, and trust, while Arkush (1984) concluded that the underlying value of the entrepreneurial spirit is hard work.

Accuracy in perceiving the value of the lecturer is more likely occurrence if there is an agreement between lecturer and student grades in school (Knafo \& Schwartz,2009). The deal faculty and students can provide a more consistent value message and not confuse and easier to be understood accurately. Due to the students tend to look to their teachers as models, they might capture more of the value of the lecturer is the message and understand it quite accurate, even though there is disagreement with the professor.

From the above transmission process, the communication between faculty and students is very important. Effective communication must occur between faculty and students, in this case, aims to equalize the values to be transmitted between faculty and students to avoid misperceptions. Communication between faculty and students is intended to convey and instill these values in students. Hill and Taylor (2004) found that the communication will be effective and appropriate if the professor is also involved in the activities done by the students. In other words, the lecturer is not only advised but also to set an example and take the time to understand the needs of students, so that students are willing to listen to his teachers, who will be the beginning of the received values instilled by lecturers.

\section{ENTREPRENEURIAL IMPROVED SELF EFFICACY (ESE)}

Bandura (in Schunk, 1990) defines self-efficacy as consideration a person's ability to organize and action required to achieve a certain performance. Self-efficacy is also defined as an opinion or belief that a person has about his ability to perform a form of behavior, and this corresponds to the situation faced by these people, and put it as a cognitive element of social learning.

Efficacy determines how much effort will do and how people survive in the face of obstacles and painful experience. The stronger the individual's perception of self-efficacy greater the effort she'd give. When faced with difficulties, people who have great doubts about their ability to reduce their efforts or give up altogether. While those who have a strong sense of accomplishment will use greater efforts to overcome the challenges (Bandura, 1986).

Bandura (1997) proposed two different ways to reinforce the efficacy of the students. The first one produced through support, encouragement, and positive modeling. For example, if a student-student who was given the challenging task in entrepreneurship courses, are encouraged to perform these tasks, and given the credit will have a higher self-efficacy. The second one comes from experience through learning to cope with adverse conditions encountered. Table 2 gives an overview of examples of things that could potentially affect self-efficacy in various stages of development of students.

Table 2. Potential Factors Affecting Student Self Efficacy

\begin{tabular}{lllll}
\hline & Experience & $\begin{array}{l}\text { experience } \\
\text { Vicarious/modeli } \\
\text { ng }\end{array}$ & $\begin{array}{l}\text { Persuasionsocial / } \\
\text { verbal }\end{array}$ & $\begin{array}{l}\text { judgment on the } \\
\text { psychological } \\
\text { state of }\end{array}$ \\
\hline $\begin{array}{l}\text { Infancy and Early } \\
\text { Childhood (house, } \\
\text { kindergarten, and } \\
\text { preschool) }\end{array}$ & $\begin{array}{l}\text { The selection of } \\
\text { toys and activities }\end{array}$ & $\begin{array}{l}\text { Reference group: } \\
\text { Teachers, parents }\end{array}$ & $\begin{array}{l}\text {-Fables } \\
\text {-TV Shows } \\
\text {-Kindergarten } \\
\text { teacher }\end{array}$ & $\begin{array}{l}\text { Exercise and } \\
\text { physical activity }\end{array}$ \\
$\begin{array}{l}\text { Teen(schools, secondary } \\
\text { schools) }\end{array}$ & $\begin{array}{l}\text { Participation in } \\
\text { self-employment } \\
\text { at a higher level. }\end{array}$ & $\begin{array}{l}\text { Reference groups: } \\
\text { teachers, peers }\end{array}$ & $\begin{array}{l}\text {-Media } \\
\text {-Lecturer } \\
\text {-How to teach and } \\
\text { reward } \\
\text { appropriate } \\
\text { behavior }\end{array}$ & $\begin{array}{l}\text { activity and } \\
\text { physical exercise: } \\
\text { participating in } \\
\text { entrepreneurial }\end{array}$ \\
& & & $\begin{array}{l}\text {-Lecturer } \\
\text {-media }\end{array}$ & $\begin{array}{l}\text {-Participation in } \\
\text { self-employment } \\
\text { at a higher level }\end{array}$ \\
\hline $\begin{array}{l}\text { Young Adults } \\
\text { (University) }\end{array}$ & Participation in \\
entrepreneurial & reference group: & family, peer, & & \\
\hline
\end{tabular}


activity at a

higher level entrepreneurs who -Coach and mentor

are successful
-Prepare for and attend a written test and practice

Source: Bandura (1997)

\section{CONCLUSION}

From the above discussion, it can be seen that the study concluded first, the general intention of entrepreneurship students are still relatively low evidenced by lack of individual and group FEB students become entrepreneurs, lack of student involvement in the training and equipping of entrepreneurship within and outside the campus environment and the lack of the number of business proposals that competed in the Student Entrepreneurial Program (PMW) Higher Education.

Second, the low propensity to entrepreneurship intention is strongly influenced by the lack of support for parents and families that the majority of employees and private sector employees, and the public perception of climate entrepreneurial learning and academic support.

Third, the solution offered is to multiply the frequency of entrepreneurial practice, implement contextual learning a periodic basis, provide and equip the facility entrepreneurship on campus, held a business incubator program and business plan writing contest, an increase in the budget allocation of student entrepreneurship and develop entrepreneurial network integrated with local stakeholders.

Lecturer very important role in the development of entrepreneurship in the student intentions. However, not many lecturers are aware of this and more on the formal education system to perform the task. Basically, all the parties responsible for the education of entrepreneurship, cooperation between them is very important, because a comprehensive education will bring results more mature than the work done sporadically and partially. Furthermore, we need to realize that this article is not sufficient to discuss the formation of a vibrant and entrepreneurial competence on student-to-student. Need further discussion that takes into account other aspects such as personality and motivation for entrepreneurship.

Alternative ways to do FEB Unitomo to increase the interest of student entrepreneurship including through (a) multiplying the frequency of the practice of entrepreneurship, dissemination, and access to information about entrepreneurship in internal campus also opened widely to students, (b) implement contextual learning periodically in the form of studies field on Micro, Small and Medium Enterprises (SMEs) in the campus area mainly owned and managed by alumni, (c) provide and equip facilities entrepreneurship in the campus, such as laboratories, galleries, workshops and the like in this case Unitomo has Unitomo Street food as a living laboratory of entrepreneurship, (d) organize special programs such as business incubators and competitions of writing a business plan for the student (business plan) with the prize / bonus a certain impact on the increased interest and skills in entrepreneurship, (e) the allocation of sufficient budget to groups yan student -group $\mathrm{g}$ as through specific selection and qualified prospects to develop the business, and (f) developing an integrated entrepreneur development network with local stakeholders who have similar programs such as the Department of Cooperatives, Industry and Trade, Bank Indonesia and the Chamber of Commerce and Industry in Surabaya.

\section{REFERENCE}

Ajzen, I. (1991). "The Theory of Planned Behavior", Organizational Behavior and Human Decision Processes, 50 (2), pp. 179-211.

Andika, M., \& Madjid, I. (2012). Analisis Pengaruh Sikap, Norma Subyektif dan Efikasi Diri Terhadap Intensi Berwirausaha Pada mahasiswa Fakultas Ekonomi Universitas Syiah Kuala. In Eco-Entrepreneurship Seminar \& Call for Paper" Improving Performance by Improving Environment. 190-196.

Arkush, R. D. (1984). "If Man Works Hard the Land Will Not Be Lazy": Entrepreneurial Values in North Chinese Peasant Proverbs. Modern China, 10(4), 461-479.

Badan Pusat Statistik. (2017) Keadaan Ketenagakerjaan Agustus 2017. Berita Resmi Statistik Badan Pusat Statistik, (74/11).

Bandura, A., Reese L., \& Adams N.E. (1986). Microanalysis of Action and Fear Arousal as a Function of Different Levels of Perceived Self Efficacy, Journal of Personality and Social Psychology, 43, 1, 5-21.

Bandura A (1997). Self-efficacy The Exercise of Control. W.H. Freeman and Company, New York 
Berkowitz, A. D. (2004). The social norms approach: Theory, research, and annotated bibliography.

Bird, B. (1988). Implementing entrepreneurial ideas: The case for intention. Academy of Management Review, 13(3), 442-453.

Borsari B \& Carey, KB. (2003). Descriptive and Injunctive Norms in College Drinking: A Meta-analytic Integration. Journal of Studies on Alcohol, 64:331-341.

Carr, J. C., \& Sequeira, J. M. (2007). Prior family business exposure as intergenerational influence and entrepreneurial intent: A theory of planned behavior approach. Journal of Business Research, 60(10), 10901098.

Cahyono, H. (2017) 'Abnormal Return Differences Before And After Amnesty Tax Policy 2016-2017 Period II And III (Event Study at Company divided in LQ45 Index)', IJEBD (International Journal of Entrepreneurship And Business Development), 1(1), pp. 39-74.

Puspitasari, E. and Harjanti, W. (2017) 'Meaningful Experience Of Motivation To Power Seller With Orientation On Consumer Satisfaction For Identification Of Employee Benefits In The Textile Sales In South Surabaya', IJEBD (International Journal Of Entrepreneurship And Business Development), 1(1), pp. 1-22.

Syaifudin, A. (2017) 'The Impact of Creativity and Innovation on Increasing Micro Enterprise Income PKL Gading Fajar Sidoarjo', IJEBD (International Journal Of Entrepreneurship And Business Development), 1(1), pp. 88-98. Available at: http://jurnal.narotama.ac.id/index.php/ijebd/article/view/349 (Accessed: 1 November 2017).

Fishbein, M. \& Ajzen, I (1975). Belief, Attitude, Intention, and Behavior: an Introduction to Theory and Research. Reading, MA: Addison-Wesley.

Fishbein, M. \& Ajzen, I. (2010). Predicting and Changing Behavior. New York : Psychology Press.

Gecas, V. (1989). The Social Psychology of Self-efficacy. Annual Review of Sociology, 15: 291-316.

Grusec, J. E., \& Goodnow, J. J. (1994). Impact of parental discipline methods on the child's internalization of values: A reconceptualization of current points of view. Developmental Psychology, 30, 4-19.

Galloway. L. 2006. Identifying Entrepreneurial Potential in Students. Working Paper 006, National Council for Graduate Entrepreneurship

Gurbuz, G \& Aykol, S. 2008. Entrepreneurial Intentions of Young Educated Public in Turkey. Journal of Global Strategic Management, 4(1): 47-56.

Hill, N. E., \& Taylor, L. C. (2004). Parental school involvement and children's academic achievement pragmatics and issues. Current directions in psychological science, 13(4), 161-164.

Johnston, K. A., et al. 2010. Identifying ICT Entrepreneurship Potential in Students. Proceedings of Informing Science \& IT Education Conference (InSITE), (June): 21-24.

Kecharananta, N., \& George Baker, H. (1999). Capturing entrepreneurial values. Journal of Applied Social Psychology, 29(4), 820-833.

Khuong, M.N. \& An, N. H. (2016). The Factors Affecting Entrepreneurial Intention of the Students of Vietnam National University - A Mediation Analysis of Perception toward Entrepreneurship. Journal of Economics, Business and Management, Vol. 4, No. 2.

Knafo, A., \& Schwartz, S. H. (2009). Accounting for parent-child value congruence: Theoretical considerations and empirical evidence.

Kristiansen, S., \& Indarti, N. (2004). Entrepreneurial Intention Among Indonesian and Norwegian Students. Journal of Enterprising Cuture 12 (01), 55-78.

Krueger, N. F., Reilly, M. D., \& Carsrud, A. L. (2000). Competing models of entrepreneurial intentions. Journal of business venturing, 15(5), 411-432.

Mueller, S. (2008). Increasing Enterpreneurial Intention: Effective Enterpreneurship Course Characteristics. Int. J. Entrepreneurship and Small Business, Vol. 13, No. 1, 2011, 55 - 74.

Obschonka, M., Silbereisen, R.K., \& Schmitt-Rodermund, E. (2010). Entrepreneurial intention as developmental outcome. Journal of Vocational Behavior, 77(1), 63-72.

Robinson, P. B., Stimpson, D. V., Huefner, J. C., \& Hunt, H. K. (1991). An attitude approach to the prediction of entrepreneurship. Entrepreneurship theory and practice, 15(4), 13-31. 
Rosenberg, M. J., \& Hovland, C. I. (1960). Cognitive, affective, and behavioral components of attitudes. Attitude organization and change: An analysis of consistency among attitude components, 3, 1-14.

Schunk, D.H. (1990). Introduction to the Section on Motivation and Efficacy, Journal of Educational Psychology, 82 (1), 3-6. 